\title{
Soil Analysis as a Pedagogical Strategy in High School with PBL Methodology
}

\section{Cristiane Heredia Gomes ${ }^{1}$, Natália Borges Pinheiro', Isabel Cristina Teixeira da Silva1, Vanessa Fagundes Siqueira1, Cássius Fernandes Mirapalhete ${ }^{1}$, Rafael Lima Dessart ${ }^{2}$}

\author{
${ }^{1}$ Universidade Federal do Pampa, Caçapava do Sul, Brazil \\ ${ }^{2}$ Universidade Federal do Paraná, Curitiba, Brazil \\ Email: cristianegomes@unipampa.edu.br
}

How to cite this paper: Gomes, C. H., Pinheiro, N. B., da Silva, I. C. T., Siqueira, V. F., Mirapalhete, C. F., \& Dessart, R. L. (2018). Soil Analysis as a Pedagogical Strategy in High School with PBL Methodology. Creative Education, 9, 932-941. https://doi.org/10.4236/ce.2018.96068

Received: April 28, 2018

Accepted: May 20, 2018

Published: May 23, 2018

Copyright $\odot 2018$ by authors and Scientific Research Publishing Inc. This work is licensed under the Creative Commons Attribution International License (CC BY 4.0).

http://creativecommons.org/licenses/by/4.0/

\begin{abstract}
This study aims at discussing the implementation of Problem Based Learning (PBL) in activities carried out in a first grade high school class. The analysis of soil was used as a didactic tool capable of facilitating student teaching and learning, and as a way for understanding the environment that surrounds them, aiming at achieving three main goals: to acquire knowledge, to develop skills, and attitudes. During the activities, it was noticed a great student involvement with the activities, especially in the practical ones. In that sense, it was concluded that it is important to work with active methodologies, which are able to increase interest and motivation in the students. Thus, through a thematic approach, it is possible to raise students' critical awareness.
\end{abstract}

\section{Keywords}

Soil Analysis, High School, Pedagogical Strategy

\section{Introduction}

This paper presents the results obtained though the employment of active methodologies in Geosciences in high school. The activities were developed by academics from the undergraduate courses of Exact Sciences and Geology from the Federal University of Pampa (Unipampa), under the supervision of Dr. Cristiane $\mathrm{H}$. Gomes, in a first year high school class, in the subject of chemistry. The study sought to relate the studies of soil analysis with the concepts from chemistry studied in class.

According to Ribeiro et al. (2014), the goal of the analysis is to ascertain the characteristics and properties of the soil, thus determining its fertility through chemical and physical procedure. For Camargos (2005), the greater the necessity 
of soil nutrients and productivity, the more this method will be enhanced. In this sense, Ruelan and Dosso (1993) believe that soil is the most complex natural resource in the environment, being its study a means for conducting qualitative systematic analysis.

According to the National Curricular Parameters (PCN) for high schools (Brasil, 2006), the theoretical contents approached for teaching Chemistry must relate to the everyday life and the reality of the students, allowing them to connect different areas of knowledge. In this context, it is noted that "the educational system must develop actions and strategies that allow students to understand the impact their actions might cause in the environment around them" (Gomes et al. 2005: p. 9).

In this regard, working with a specific theme is characterized as an important possibility for the development of real themes in the classroom (Delizoicov et al. 2001: p. 189). Hence, it is important that the teacher chooses a theme that is part of the reality of the students as well as demonstrates relevance to their lives. In addition, it is necessary to select curriculum subjects that are directly related to the theme for a better comprehension of the subject.

In consonance, when discussing the thematic approach to teaching Chemistry, Richetti and Alves Filho (2009) argued that the contents of Chemistry, once they are directly linked to the people's daily lives, have the potential to provide understanding of the chemical phenomena related to everyday life, therefore giving meaning to these contents and facilitating the interpretation of those phenomena.

In this perspective, Delizoicov (2007: p. 47) emphasizes that:

There must be criteria to establish which phenomena and situations are important and relevant for the understanding of students in today's schools [...] and criteria to select the consequent knowledge produced over the phenomena and situations chosen, in that they become school content.

In this context, it is highlighted the importance of the theme on the study of soil in high school, since by approaching subjects that belong to the environment in which these students are inserted in, it becomes possible to arouse their interest and criticality on the studied subject. Soil, in this sense, is relevant once it is "the result of different geological formations, of various types of climate, of many vegetation formations, of a variety of landforms, of time and, yet, of the most various ways of using and human occupation" (Ruelan and Dosso, 1993: p. 19).

Auler (2007) agrees with the importance of a distinct study in the Teaching of Sciences, that discusses and brings together "the world of school" to "the world of life", thus emphasizing the importance of working themes that are directly related to the daily life of the students. For Delors (1998: p. 153):

As the division between the classroom and the world outside becomes less rigid, also the teachers have to make an effort to extend the educational 
process outside the school, organizing learning experiences conducted in the outside, and, in terms of content, establishing a connection between what is taught to the everyday life of the students.

Borges \& Alencar (2014) discuss about the search for a better practical acting in the classroom through the use of alternative methodologies. The active methodology has contributed for a critical formation of the student as well as preparing them to search for knowledge from sources other than the teacher (Rezende Jr. et al., 2016). There are many active methodologies; one of them is Problem Based Learning (PBL). This methodology is characterized by the use of problems from the real world in order to encourage students to develop critical thinking and the ability to solve problems, acquiring constant knowledge about the essential concepts of the area in question.

The use of PBL in high school and graduation develops the critical, autonomous, and active formation of future professionals, building up skills for professional group work, initiative, leadership, and planning. According to Borges et al. (2014), the use of PBL in groups allows for a network of interactions among individuals, from which the person can refer to in others, meet with others, differentiate themselves from others, oppose to them, and still transform and be transformed by them, in the construction of knowledge. Therefore, using PBL attempts to meet students' anxieties, in the sense that they are more and more integrated to the process of knowledge construction and not acting and as passive receptors in the identification and solution of the scientific problem.

Gijselaers (1996: p. 3) suggests that PBL contemplates three fundamental principles of learning:

Learning is a constructive process, not a receptive one-knowledge is structured in networks of concepts related among themselves and the new concepts are learned as they are related to the preexisting networks, thus, making it paramount to activate previous knowledge of the students when the subject in question as a way of allowing the learning of new concepts related to it; 2) metacognition affects learning-skills such as the establishment of objectives (what am I going to do?), the selection of strategies (how am I going to do?), and the evaluation of results (did it work?) are considered essential to learning; and 3) contextual and social factors influence learning-the context in which teaching happens favors or inhibits learning, thus, learning is optimized when the content being taught is close to the future professional context of the students, and when students share responsibilities and different views about the same content, making students deepen their questioning about the content and develop skills such as critical sense, acceptance of different opinion, construction of a consensus, etc.

According to Gemignani (2012), the set of activities implicated that students undertake the seven following tasks: 1) presentation of the problem; 2) clarifica- 
tion of some less known conceptual terms and doubts about the problem; 3) definition and synthesis of the problem in question, identifying the areas and relevant aspects; 4) analysis of the problem using previous knowledge; 5) development of hypothesis to explain the problem and identification of knowledge gaps; 6) definition of learning objectives and identification of the appropriate learning resources; and 7) search for information and individual study.

It is important to emphasize that, even being based on learning through means of problem-solving, PBL is not merely a technique to solve issues. Techniques on problem-solving are fundamental in this educational approach, however, PBL cannot be summarized by them. Problem-solving is only one of the tools of PBL.

From the discussion presented above, this study aims at portraying an experience in using the PBL active methodology in a high school class of the Technical School Rubens da Costa Guedes (Eterg), in Caçapava do Sul/RS. The study focuses on how students from high school and undergraduate evaluate this teaching approach, its advantages and disadvantages, and their capability of achieving the objectives proposed by practice, for instance, knowledge, skills, and attitudes.

\section{Methodology}

The intervention-research of qualitative nature adopted a collaborative approach (Cole \& Knowles, 1993), in the sense that the planning, implementation, and analysis of the results were a conducted along with professor Dr. Cristiane Heredia Gomes and undergrad students from the courses Bachelor in Earth and Exact Sciences, and Geology from the Federal University of Pampa (Unipampa), as an activity of the curricular component Earth System.

The course Earth System is a mandatory curricular component in the professional core of various courses, such as: Sanitary and Environmental Engineer, Geology, Geophysics, Mining Technology, and Bachelor in Exact and Earth Sciences.

To answer the research question of this study so as to evaluate the use of PBL along with students, the PBL methodology was carried out along with the disciplines of General Chemistry in the first year of high school at Eterg.

The class in question had a total of 29 students, who participated in the study, and from which 20 were male and 9 were female. These students aged between 13 and 15 years old.

The data collection comprised interviews, participant observation, and questionnaires. The data showed in this paper derives mainly from classroom observations and one final questionnaire applied at the end of the semester which was answered by the 29 students. This questionnaire was applied individually and in written form, and asked students to evaluate the methodology used, to point out its advantages and disadvantages, to offer suggestions for improvement, and give opinions about its efficacy in meeting the goals proposed by the discipline. 
The study was based on the set of activities and guiding principles of PBL. The actives were carried out weekly, for four weeks, with two weekly meetings of 1 hour and 40 minutes. The theoretical classes were carried out in the classroom using the white board, with a computer connected to the internet and a projector. As for the practical classes, those were carried out in a green area around the school building, and in the Sciences Laboratory.

In the first meeting, the content presented was related to the geologist as a profession, its principles and procedures-the objectives related to the contents (the movement of thought about geology), to the skills (problem-solving, related skills, etc.), and to the attitudes (respect to the opinion of others, cooperation, etc.) - under the light of the following theme: "The geologist and the profession of geologist". In this moment, the content was reviewed through a debate, and there was an attempt to relate the concepts known by the students to the theme elaborated. In the second meeting, the experimental activity of soil collection was carried out. The samples were retrieved from different points in the school, such as the vegetable garden and the center for animal management. The students divided themselves into groups of 4 or 5 , in which they switched between the roles of leader, writer, spokesperson, and participants, with the goal of fostering the exchange of experiences in relation to the collective work and promote its efficacy.

In the third meeting, after collecting the samples, students were taken to the Laboratory of Mineralogy and Petrography of the university, so that they could accompany the process of analysis through X-ray of the soil samples and identify the chemical elements in the sampled soil. Students analyzed the problem (results of the analysis) and its possible causes (importance and toxicity of the chemical elements of the soil), listed learning questions that could aid them in its solution (for instance, "what is the kind of soil of this region?", "what kind of rock formed this soil?"), and planned their work strategy in groups on that week. On the fourth and last meeting, students wrote and handed in a final report with the results of the research, a synthesis of the concepts used and the solutions proposed by the groups, which were orally presented by the spokesperson.

The presentations of the groups were followed by a collective closing, for instance, a debate between the high school students, the undergrad students, and the professor, as well as a synthesis of the set of activities carried out about the topic in question. Finalizing the intervention-research, the groups evaluated the problem and the educational process, and the undergraduate students evaluated, individually, their own work.

\section{Analysis of the Results}

The results presented in this study were obtained by means of qualitative analysis, through questioning, discussions, and observations carried out during activities aimed at providing students of the first year of high school a greater comprehension of the environment they are inserted in, and thus contribute with 
learning, knowledge, skills, and attitudes.

In general, the evaluation of most of the students about the implementation of the used teaching methodology was positive. The interest in the subject can be accredited to the direct contact of these students to the theme, since the majority of them lives in the countryside of the city, where the development of agriculture is immense. This fact can be highlighted through the following comments given during the activities: "My father plants and he is always worried with the quality of the soil, many times he has to fertilize it" (A15); "So they put limestone in the farm land to correct the $\mathrm{pH}$ ' (A17).

Another explanation for the students' enthusiasm in the subject might be the fact that they study in a school that offers a Technical Course in Agricultural Sciences, which usually conducts activities that are different from regular schools. Unfortunately, the students who took part in the activity form this study do not participate in those different activities. In this sense, it is possible to notice, in the development of the activities, the interest that arose on students in studying the concepts that are related directly to their everyday activities. Therefore, teachers showed motivated and excited, looking for information that promoted students' scientific independence to enhance their knowledge on the soil investigated. As Leite et al. (2000) emphasize, the development of new competencies requires students to be actively involved in the learning processes and that they feel motivated to learn.

The expository class addressed the diversity of geological contexts in the city of Caçapava do Sul, which is considered as "the gaúcha capital of geodiversity". In addition, this class explained about the profession of geologist and the course of Geology, in that moment, it was possible to notice great interest from the students, as they were all focused on the explanations from the monitors. When they asked the questions about how the rocks of the region were formed and how the geologist investigates these formations, students changed their semblance, since they were unaware of most of the information that was presented in the answer to their questions. The fact that students lack knowledge about the geology of their city leads us to understand how important it is to highlight the relevance of knowing the geological environment in which we live. Gomes et al. (2005) pinpoint that it is the role of the educational system to elaborate practices and methodologies that provide students with the understanding of the influence their attitudes produce in the environment around them, especially in relation to the degradation or lack of care with the environment.

In the soil collection, the students understood of the importance of the geologist as a profession in planning strategies and collecting samples. The monitors explained about the use of the materials, such as the valve and the GPS; the adequate procedures for soil collection, its storage and identification; as well as the best places for extraction. At this stage, it was possible to notice great participation and performance from the part of the students, once almost all them tried to participate, aiming at riding the theory from the classroom with the practice. 
From the students it was noted that their attitude was more argumentative, in that they demonstrated to be more attentive to the steps of the collection process, asking about the concepts involved in the activity. Besides being an action they have never done before, it was observed that they felt free to ask questions and show their opinion.

It was noticed that students seemed to be afraid at the beginning, but that as the activity went by and some doubts were brought up, the students took the opportunity to understand, through the interaction, the concepts that were being exposed. The advantages that were most pointed by students were related to bridging the gap between practice and theory, as the comments illustrate: " $I$ learned much more about soil in the sampling than in a month of theoretical class" (A3); "For me it was a constructive experience" (A4); "I think this class was very different, because we left the classroom to have the chance to get to know better what is around us" (A5). In those sentences, it is possible to verify the importance of field class in order to contextualize the reality.

In the visitation to the university for the analysis of the collected samples, all the class was present, which shows a great interest from the students in participating in the project. One of the students, on his own initiative, took his rock collection in the day of the analysis so they could be identified by the undergrad students. During the analysis of the soil in the X-ray equipment, the students demonstrated to be participative, raising hypothesis and asking for clarification, as the reports show: "I like the analysis very much, I had never seen one in my life" (A6); "The equipment did the analysis very quick, it only took a few seconds and you could already know the chemical part of the sample" (A9); "If we had this equipment in our school, it would not take so long to find out what the soil needs" (A8); "We could analyze not only the soil, but also the vegetables we produce to know if they are healthy or if there is lack of any chemical element" (A7).

Visiting the university was very productive. Most of the students had never been there, which arouse the curiosity about the available courses, leading high school students to look for more information about them.

In the discussions about the results obtained from the analysis of the soil, the elements found in the samples, as well as their quantities, importance and toxicity were discussed. In that occasion, it was noted that students were concentrated in the results obtained, questioning the reason some soils contain elements that others do not (A11), and how this would influence in soil quality and how to improve soil productivity for the school vegetable garden (A13).

The enthusiasm and interest demonstrated highlight the efficacy of the project, since through a theme that involved the everyday life of the students. It was possible to estimate their will to learn. The school, in its turn, was very satisfied with the repercussion of the proposal, demonstrating interest in implementing it in other groups. In the end of the activities, the reports of the analysis of the soil were made available to the school. 
The advantages and disadvantages pointed out by students were related to the capacity of the methodology in promoting research and autonomous learning: "Through the chemical analysis we could present solutions to the problems of the soip" (A15); "The advantage of not receiving all the material makes us research, and thus we learn more!" (A18); "The research with real data makes it easier to interact with the practical problems in a farm, and the discussion on the theme occurred naturally" (A20); "The way the methodology was used promoted better interaction in the group" (A16); "The knowledge of the profession of geologist made me see how interesting this job is" (A18).

However, there were also suggestions of improvement, such as the fact that this methodology could be used more often (A3); that there should be more debate between students and teachers (A6); that there should have a coordinator (tutor) for each group so as to guarantee the participation of all students (A23); and a better use of the time in class for the group work (A28).

About the knowledge, skills, and attitudes, the great majority of students evaluated that the goals of the activity were reached: "Yes, because I learned with pleasure and I want it to become my profession" (A10); "The goals were reached in that all students worked together to solve the problems" (A17); "The knowledge gained by the research were better learned as opposed to a theoretical class" (A1); "The activities were very nice, we had never done something like this, it was a loss because we are became more interested in learning the school contents" (A18); "Besides group working not being something good, in this group I learned how to analyze data and find solutions for them" (A5); "In the first meeting everyone seemed lost [...], but in the last one it was easy to notice the progress of the class, that based on the knowledge previously acquired produced better discussions and felt safe to give their opinion" (A9); "I had not noticed how chemistry is important and that it is everywhere, as I could notice in the nutrients that make the vegetables grow so that we can eat them" (A3).

Hence, from the discussion presented, it can be noticed the importance of conducting practical activities related to the everyday life of the students, so that it becomes easier to motivate them to understand and seek knowledge, in addition to promoting critical awareness. In this sense:

[...] it is not enough that students simply remember the information: they must have the ability and the desire to use it, they need to know how to relate it, synthesize it, and evaluate it. Together, these elements constitute critical thinking that arises in the class when students make an effort to move beyond the simple answers, when they defy ideas and conclusions, and try to bring together non-related events into a coherent understanding of the world (Mercado, 2002: p. 25).

\section{Conclusion}

In the end of the study, it was possible to observe how efficient it was to contextualize the contents about a real theme. During the study, the undergraduate 
students noticed the effort and motivation raised in the high school students, not only about the concepts studies but also about the course of Geology itself, as they demonstrated interest in continuing their studies in this area.

Through the activities, it can be concluded that it is important to work with the proposed theme. All groups were able to structure the problem directly related to their everyday lives and build a database to come to the resolution of the problem, which allowed for successful application of the PBL methodology. The interest of the students in the area is related to the fact that Caçapava do Sul is the capital of geodiversity, thus a fruitful place for diversity of rocks, and that Unipampa offers a course in Geology.

Even with time limitations-only two weekly meetings, it was possible to observe the effective promotion of student learning, the convergence between theory and practice, and between knowledge gained and future professional life. Thus, working on a real problem, besides developing students' critical thinking, allows for a better understanding of the contents worked in class, chemistry for instance, which is also present in their daily lives.

It can be noted, in this context, the need to bring together the scientific concepts about geology discussed in basic schooling to their lives outside school. Aspects such as this are essential to promote critical education, in a way that they become citizens able to intervene positively in the society they belong to. In this perspective, it is highlighted the importance of discussing themes that are part of the reality of these students. In order to do so, it is necessary to previously investigate the problems of the region in which the student lives, so that it is possible to promote a dialogic and problematizing education (Freire, 1987).

Therefore, the study concludes the need for the teacher to search for alternative active methodologies, such as $\mathrm{PBL}$, that aim at promoting students' cognitive development so that they can better understand the phenomena in their everyday lives. In this sense, Freire defends practices that motivate the learner, instigate reflection, and develop critical thinking. Freire, thus, defends curricular restructuring that is grounded on thematic approach, discussing real problems and having life the point of departure (Freire \& Shor, 1986; Freire, 1987).

\section{Acknowledgements}

The authors are thanked Unipampa (grant 375/2016) for the financial support for the Fellowship in Academic Development Program (PDA) to N.P. Borges.

\section{References}

Auler, D. (2007). Enfoque ciência-tecnologia-sociedade: Pressupostos para o contexto brasileiro. Revista Ciência e Ensino, 1, n. especial.

Borges, T. S., \& Alencar, G. (2014). Metodologias Ativas na Promoção da Formação Crítica do Estudante: $\mathrm{O}$ uso das Metodologias Ativas como recurso didático na Formação Crítica do Estudante do Ensino Superior. Cairu em Revista, 3, 119-143.

Brasil. (2006). Ciências da natureza, matemática e suas tecnologias/Secretaria de Educação Básica. Brasília: Ministério da Educação, Secretaria de Educação Básica. 
Camargos, S. L. (2005). Fertilidade dos solos: Parte Prática. Cuiabá, MT: Departamento de Solos e Engenharia Rural Disciplina Solos I.

http://www.ebah.com.br/content/ABAAAAq6wAH/amostragem-solos-analise-quimica

Cole, A. L., \& Knowles, J. G. (1993). Teacher Development Partnership Research: A Focus on Methods and Issues. American Educational Research Journal, 30, 473-495. https://doi.org/10.3102/00028312030003473

Delizoicov, D., Angotti, J. A., \& Pernambuco, M. C. A. (2001). Ensino de Ciências. Fundamentos e Métodos. São Paulo: Cortez.

Delizoicov, D. (2007). Didática Geral. Florianópolis: UFSC/EAD/CED/CFM.

Delors, J. S. (1998). Educação: Um tesouro a descobrir. São Paulo: Cortez, Brasília, DF: MEC: UNESCO.

Freire, P. (1987). Pedagogia do Oprimido (17 ed.). Rio de Janeiro: Paz e Terra.

Freire, P., \& Shor, I. (1986). Medo e ousadia: o cotidiano do professor. Rio de Janeiro: Paz e Terra.

Gemignani, E. Y. M. Y. (2012). Formação de Professores e Metodologias Ativas de Ensino-Aprendizagem: Ensinar Para a Compreensão. Revista Fronteira das Educação, 1,2 .

Gijselaers, W. H. (1996). Connecting Problem-Based Practices with Educational Theory. Bringing Problem-Based Learning to Higher Education (pp. 13-21). San Francisco, EUA: Jossey-Bass Publishers. https://doi.org/10.1002/tl.37219966805

Leite et al. (2000). Tecnologia Educacional: Mitos e Possibilidades na Sociedade Tecnológica. Revista Tecnologia Educacional, 27, 38-41.

Mercado, L. P. L. (2002). Novas tecnologias na educação: reflexões sobre a prática. Maceió: EDUFAL.

Rezende Jr. R. A. de, Deus Júnior, G. A. de, Castro, M. S., Lemos, R. P., \& Alves, R. H. F. (2016). Aplicabilidade de metodologias ativas em cursos de graduação em engenharia. COBENGE.

Ribeiro, L., Souza, F. A., Vanuchi, V. C. F., Cunha, E. M. F., \& Zan, R. A. (2014). Análise de solo como ferramenta didática para o ensino/aprendizagem de alunos da rede pública do município de JI-Paraná/Rondônia. In XVII ENEQ-Encontro Nacional de Ensino de Química, Ouro Preto, MG.

Richetti, G. P., \& Filho, J. P. A. (2009). Automedicação: um tema social para o Ensino de Química na perspectiva da Alfabetização Científica e Tecnológica. Alexandria Revista de Educação em Ciência e Tecnologia, 2, 85-108.

Ruelan, A., \& Dosso, M. (1993). Regards sur le sol(192 p). Paris: Les Éditions Foucher.

Gomes, S. S., Figueira, K. L., Brito, E. B., Silva, T. G., Rocha, M. A. G., Lima, M. C., \& Pinho, G. S. A. (2005). Experimentação num espaço alternativo: contextualizando o pH através da análise do solo da horta escolar. In 55 Congresso Brasileiro de Química. 